This PDF is a selection from an out-of-print volume from the National Bureau of Economic Research

Volume Title: International Taxation and Multinational Activity

Volume Author/Editor: James R. Hines, Jr.

Volume Publisher: University of Chicago Press

Volume ISBN: 0-226-34173-9

Volume URL: http://www.nber.org/books/hine00-1

Conference Date: November 14-15, 1997

Publication Date: January 2000

Chapter Title: International Taxation and the Location of Inventive Activity

Chapter Author: James R. Hines Jr., Adam B. Jaffe

Chapter URL: http://www.nber.org/chapters/c10725

Chapter pages in book: (p. 201 - 230) 


\title{
International Taxation and the Location of Inventive Activity
}

\author{
James R. Hines Jr. and Adam B. Jaffe
}

\subsection{Introduction}

Tax systems often encourage certain activities at the expense of others. Governments typically offer very attractive tax treatment to investments in research and development ( $R \& D$ ), because $R \& D$ is thought to be associated with large positive economic spillovers. ${ }^{1}$ One of the factors contributing to the generosity of tax benefits for R\&D is competition among governments to attract R\&D-intensive investments by multinational corporations (MNCs). Because an MNC typically has the option of performing its $R \& D$ in any of several countries, the volume of its $R \& D$ activity in one country is likely to be affected by the attractiveness of opportunities elsewhere. In spite of the frequency with which $R \& D$ receives generous tax subsidies, and the widespread belief that these subsidies encourage the discovery and development of new technologies, very little of a quantitative nature is known about the impact of tax rules on the international location of innovative activity.

The purpose of this paper is to examine the effect of taxation on the distribution of inventive activity between the United States and foreign countries. The paper analyzes the effect of U.S. tax changes, particularly those introduced by the Tax Reform Act of 1986, on the international pattern of subsequent patenting by U.S. multinationals. Due to the spe-

James R. Hines Jr. is professor of business economics at the University of Michigan Business School and a research associate of the National Bureau of Economic Research. Adam B. Jaffe is chair of the Department of Economics at Brandeis University and a research associate of the National Bureau of Economic Research.

The authors thank Austin Nichols for excellent research assistance, Austan Goolsbee for helpful comments on an earlier draft, and the NBER for financial support.

1. Griliches (1992) surveys the econometric evidence of economic spillovers from innovative activity. 
cifics of U.S. tax law, U.S. firms differ in the extent to which tax changes affect their after-tax costs of performing R\&D in the United States. Firms also differ in the extent to which tax changes affect the returns to using the results of R\&D performed in the United States to generate sales abroad. The same U.S. tax changes do not directly influence the return to R\&D performed abroad by U.S. multinationals, so any induced international relocation of innovative activity in the years following tax changes reflect the ways in which domestic and foreign patenting activity are related.

There is extensive interest in understanding the role that MNCs play in transferring technologies across borders. There are two methods by which MNCs provide technology to the countries in which they invest. The first method is to develop new technologies locally, through R\&D or other similar types of activity. The second method is to import technologies produced elsewhere.

The foreign affiliates of U.S. firms use both methods to bring technologies to the countries in which they invest, and there exists sufficient information to assess quantitatively the relative significance of each method. Direct information on the R\&D activities of the foreign affiliates of U.S. firms is reported in surveys conducted by the U.S. Department of Commerce. Information on technology imports by these affiliates is considerably sketchier. One can, however, infer the approximate magnitude of technology imports from royalties paid by affiliates to U.S. parent firms and third parties in other countries, because royalty payments should, in principle, reflect the values of imported technologies.

Table 8.1 reports detailed information on the aggregate technologyrelated behavior of the foreign affiliates of U.S. firms in 1982, 1989, and 1994. It is noteworthy that affiliates paid more in royalties to their parent firms ( $\$ 16.7$ billion in 1994) than they spent on $\mathrm{R} \& \mathrm{D}$ ( $\$ 11.9$ billion in 1994), although, as the table indicates, there was extensive use of both methods of technology acquisition. The survey distinguishes two categories of $R \& D$ expenditure: $R \& D$ by affiliates for themselves and $R \& D$ by affiliates for others. R\&D by affiliates for themselves constitutes roughly 80 percent of their total R\&D expenditures.

In spite of extensive consideration in the literature of the role that MNCs play in facilitating international technology transfer, ${ }^{2}$ there is very little in the way of quantitative evidence of the complementarity or substitutability of foreign and domestic technology. Hines (1995) offers evidence

2. See, for example, Teece (1976), Mansfield, Teece, and Romeo (1979), Mansfield and Romeo (1980), Davidson and McFetridge (1984), Lipsey, Blomström, and Kravis (1990), Zejan (1990), Blomström (1991), Wang and Blomström (1992), Blomström and Kokko (1995), and Ethier and Markusen (1996). These studies together consider the effect of a large number of variables on technology transfer and R\&D activity, although they do not consider the potential complementarity of domestic and foreign innovation. 
R\&D and Royalty Activity of Foreign Affiliates of U.S. Multinationals

\begin{tabular}{lrrr}
\hline & 1982 & 1989 & 1994 \\
\hline R\&D expenditures of affiliates & & & \\
Total & 3,851 & 7,922 & 11,877 \\
By affiliate for itself & 3,073 & 6,307 & 8,901 \\
By affiliate for others & 778 & 1,615 & 2,976 \\
Royalty receipts of affiliates & & & \\
Total & 435 & 1,461 & 2,581 \\
From U.S. parents & 36 & 54 & 368 \\
From other foreign affiliates & 193 & 656 & 1,096 \\
From unaffiliated Americans & 26 & 97 & 387 \\
From unaffiliated foreigners & 180 & 654 & 730 \\
Royalty payments by affiliates & & & \\
Total & 4,308 & 12,472 & 22,039 \\
To U.S. parents & 3,663 & 9,839 & 16,744 \\
To other foreign affiliates & 354 & 1,488 & 2,615 \\
To unaffiliated Americans & 102 & 660 & 2,138 \\
To unaffiliated foreigners & 189 & 485 & 543 \\
\hline
\end{tabular}

Note: Amounts are in \$ millions. Data cover majority-owned foreign affiliates of U.S. multinational firms.

Source: U.S. Department of Commerce (1985, 1992, 1996).

that domestic and foreign R\&D are substitutes, but to the extent that firms establish foreign R\&D to exploit the core competencies that they have developed at home by adapting the firms' technologies to foreign markets, we would expect that foreign and domestic R\&D would be complementary. The evidence reported in Hines (1995) is based on an analysis of aggregate data concerning the R\&D activities of U.S. multinationals abroad and the R\&D activities of foreign investors in the United States. The purpose of the current investigation is to examine whether similar patterns appear at a firm level.

The empirical results in this paper suggest that foreign and domestic innovative activities are complements rather than substitutes. Specifically, firms with rising after-tax costs of performing R\&D in the United States that is directed at generating technology for use abroad are those that exhibit the slowest growth of foreign patenting. This pattern is sensible if the willingness to undertake foreign $\mathrm{R} \& \mathrm{D}$ is a function of the propensity to perform related domestic R\&D, and the latter is a function of domestic tax incentives. What the results indicate is that domestic tax incentives can significantly influence not only the rate of domestic innovation, but also the rate of foreign innovation by U.S. multinationals. Because complementarity is a symmetrical relationship, the results also imply that foreign tax incentives should influence the rate at which U.S. multinationals innovate in their domestic markets.

Evidence of the complementarity of innovative activity comes from an 
analysis of the behavior of a panel of U.S. multinationals over the 19821992 period. There were several important U.S. tax changes over this time period, notable among them the changes introduced by the Tax Reform Act of 1986 (TRA 1986). Using international patent data that specify the inventor's country of residence, it is possible to trace the effect of U.S. tax changes on subsequent patenting patterns, and thereby to identify any effects of U.S. tax changes on foreign innovative activity (as reflected by patents).

Section 8.2 of the paper reviews the U.S. tax treatment of foreign source income, with an emphasis on the tax treatment of R\&D expenses and foreign royalty receipts. Section 8.3 presents a model of firm behavior and describes the data used in the empirical analysis. Section 8.4 presents the regression results and analyzes their implications. Section 8.5 is the conclusion.

\subsection{Tax Incentives}

The United States taxes income on a residence basis, meaning that U.S. corporations and individuals owe taxes to the U.S. government on all of their worldwide incomes. ${ }^{3}$ The top U.S. corporate tax rate is now 35 percent. Because profits earned in foreign countries are usually taxed by host governments, U.S. law permits taxpayers to claim tax credits for foreign income taxes and related tax obligations, in order not to subject U.S. multinationals to double taxation. The foreign tax-credit mechanism implies that a U.S. corporation earning $\$ 100$ in a foreign country with a 12 percent tax rate (and a foreign tax obligation of \$12) pays only $\$ 23$ to the U.S. government because its U.S. corporate tax liability of $\$ 35$ (35 percent of $\$ 100)$ is reduced to $\$ 23$ by the foreign tax credit of $\$ 12$. The foreign tax credit is, however, limited to U.S. tax liability on foreign income; if, in the example, the foreign tax rate were 50 percent, then the firm would pay $\$ 50$ to the foreign government but its U.S. foreign tax credit would be limited to $\$ 35$. Thus, a U.S. firm receives full tax credits for its foreign taxes paid only when it is in a deficit credit position - that is, when its average foreign tax rate is less than its tax rate on domestic operations. A firm has excess credits if its available foreign tax credits exceed U.S. tax liability on its foreign income. Firms average together their taxable incomes and taxes paid in all of their foreign operations in calculating their foreign tax credits and the foreign tax credit limit. ${ }^{4}$

3. Portions of this brief description of U.S. law are excerpted from Hines (1991, 1994, 1997).

4. In order to qualify for the foreign tax credit, firms must own at least 10 percent of a foreign affiliate, and only those taxes that qualify as income taxes are creditable. Furthermore, income is broken into different functional baskets in the calculation of applicable credits and limits. Income earned and taxes paid in the conduct of most types of active foreign 
Deferral of U.S. taxation of certain foreign earnings is another important feature of the U.S. international tax system. A U.S. parent firm is taxed on its subsidiaries' foreign income only when that income is repatriated to the parent corporation. This type of deferral is available only to foreign operations that are separately incorporated in foreign countries (subsidiaries of the parent) and not to consolidated (branch) operations. The U.S. government taxes branch profits as they are earned, just as it would profits earned within the United States.

The deferral of U.S. taxation may create incentives for firms with lightly taxed foreign earnings to delay repatriating dividends from their foreign subsidiaries. ${ }^{5}$ This incentive arises in those cases in which firms expect never to repatriate their foreign earnings, or if they anticipate that future years will be more attractive for repatriation (either because domestic tax rates will be lower, or because future sources of foreign income will generate excess foreign tax credits that can be used to offset U.S. tax liability on the dividends). ${ }^{6}$ It appears that, in practice, U.S. multinationals choose their dividend repatriations selectively, generally paying dividends out of their more heavily taxed foreign earnings first. ${ }^{7}$ Consequently, the average tax rates that firms face on their foreign incomes need not exactly equal the average foreign tax rates faced by their branches and subsidiaries abroad.

Branch earnings and dividends from subsidiaries represent only two forms of foreign income for U.S. income tax purposes. Interest received from foreign sources also represents foreign income, although foreign interest receipts are often classified within their own "basket" and hence are not averaged with other income in calculating the foreign tax credit. Royalty income received from foreigners, including foreign affiliates of U.S. firms, is also foreign source income. Foreign governments often impose

business operations are grouped in one basket; petroleum industry income is grouped in a separate basket; and there are separate baskets for items such as passive income earned abroad. The basket distinctions imply that a firm might simultaneously have excess foreign tax credits in the petroleum basket (which is common because foreign tax rates on oil income are typically quite high) and deficit foreign tax credits in the active income basket. Such a firm would have to pay some U.S. tax on its active foreign income, even though it has excess foreign tax credits on its petroleum income.

5. The incentive to defer repatriation of lightly taxed subsidiary earnings is attenuated by the subpart F provisions, introduced into U.S. law in 1962, that treat a subsidiary's passive income, and income invested in U.S. property, as if it were distributed to its U.S. owners, thereby subjecting it to immediate U.S. taxation. The subpart $\mathrm{F}$ rules apply to controlled foreign corporations (CFCs), which are foreign corporations owned at least 50 percent by U.S. persons holding stakes of at least 10 percent each. CFCs that reinvest their foreign earnings in active businesses can continue to defer their U.S. tax liability on those earnings. See Hines and Rice (1994) and Scholes and Wolfson (1992) for the behavioral implications of these rules.

6. It is interesting to note that the deferral of U.S. tax liability does not itself create an incentive to delay paying dividends from foreign subsidiaries, because the U.S. tax must be paid eventually. See Hartman (1985).

7. See the evidence presented in Hines and Hubbard (1990), Altshuler and Newlon (1993), and Altshuler, Newlon, and Randolph (1995). 
moderate taxes on dividend, interest, and royalty payments from foreign affiliates to their U.S. parent companies; these withholding ${ }^{8}$ taxes are fully creditable against an American taxpayer's U.S. tax liability on foreign income.

Royalties received by U.S. parent firms for R\&D used abroad represent taxable foreign source income of the U.S. firms. U.S. firms with deficit foreign tax credits must pay U.S. income tax on these royalty receipts, whereas firms with excess foreign tax credits can apply the excess credits against U.S. taxes due on the royalties, thereby eliminating the U.S. tax liability created by the royalty receipts.

Most of the world's governments impose withholding taxes on crossborder royalty payments from affiliates located within their countries. These royalty tax rates are frequently reduced according to the terms of bilateral tax treaties. For example, the United States imposes a 30 percent tax on royalties paid to foreign corporations, but this tax rate is often reduced, in some cases to zero, when recipients of royalty payments are located in countries with whom the United States has a tax treaty in force.

\subsubsection{Interaction of R\&D and Foreign Income Rules}

U.S. firms with foreign income are generally not permitted to deduct all of their R\&D expenditures in the United States against their domestic taxable incomes. Instead, the law provides for various methods of allocating $R \& D$ expenses between domestic and foreign income. The intention of the law is to retain the relatively generous treatment of $R \& D$, but only for that part of a firm's R\&D expenditures that is devoted to production for domestic markets. R\&D-performing firms with foreign sales and foreign income are presumed to be doing at least some of their R\&D to enhance their foreign profitability.

From the standpoint of taxpaying firms, the U.S. tax law's distinction between domestic and foreign $R \& D$ deductions is potentially quite important. If an R\&D expense is deemed to be domestic, then it is deductible against the taxpayer's U.S. taxable income. Alternatively, if it is deemed to be foreign, then the $\mathrm{R} \& \mathrm{D}$ expense reduces foreign taxable income for the purposes of U.S. income taxation only. Foreign governments do not use U.S. methods of calculating R\&D deductions, and generally do not permit U.S. firms to reduce their taxable incomes in foreign countries on the basis of R\&D undertaken in the United States. Consequently, an R\&D expense deduction allocated against foreign income is valuable to a U.S. firm only

8. Taxes on cross-border flows, such as dividends, interest, and royalties, are known as withholding taxes due to some of the niceties of their administration. Strictly speaking, these taxes represent obligations of the recipients and not of the payors; this arrangement permits immediate crediting of withholding taxes by recipients who are eligible to claim foreign tax credits. The taxes are called withholding taxes because the local payor is the withholding agent for the tax, and is therefore liable to ensure that the taxes are paid. 
if the firm has deficit foreign tax credits. If the firm has deficit credits, then the firm pays some U.S. tax on its foreign income, and any additional dollar of R\&D deduction allocated against foreign income reduces the firm's U.S. taxable income by a dollar. Hence, firms with deficit foreign tax credits are indifferent between allocating $R \& D$ expenses against foreign income and allocating them against domestic income. ${ }^{9}$ In contrast, firms with excess foreign tax credits pay no U.S. tax on their foreign incomes, and therefore have no use for R\&D deductions allocated against foreign income. Consequently, firms with excess foreign tax credits lose the value of any R\&D deductions allocated against foreign income.

The tax law governing the allocation of $\mathrm{R} \& \mathrm{D}$ expenses was for years rather vague, but was codified by U.S. Treasury Regulation section 1.861-8 in 1977 . The 1977 rules provide for several stages in allocating R\&D expenditures for tax purposes. R\&D in the United States that is undertaken to meet certain legal requirements (such as R\&D devoted to meeting pollution standards) can be 100 percent allocated against domestic income. Firms that perform more than half of their (other-than-legally-required) R\&D in the United States are permitted to allocate 30 percent of that R\&D against U.S. income. The remaining 70 percent is then to be allocated between domestic and foreign sources on the basis of sales (including the sales of controlled foreign corporations [CFCs]). R\&D is generally allocated according to activities within product lines (defined similarly to two-digit Standard Industrial Classification [SIC] codes), so that a corporation need not allocate part of its chemical $R \& D$ against foreign income simply because the electronics part of its business has foreign sales.

Several options are available to taxpayers who are unsatisfied with the outcome of the R\&D allocation method just described. A firm is permitted to apportion more than 30 percent of its domestic R\&D against U.S. income if it can establish that it is reasonable to expect the R\&D so apportioned to have very limited application outside the country; the remaining portion of its R\&D expenses are then allocated on the basis of sales. Alternatively, a firm is permitted to allocate its $R \& D$ on the basis of total foreign and domestic income (though without the 30 percent initial allocation to U.S. source), so that a firm with foreign operations that generate sales but not income (relative to domestic operations) might prefer the income allocation method. There is, however, a limit to the income allocation method: A firm is not permitted to reduce its foreign source R\&D expense allocation to less than 50 percent of the allocation that would have been produced by the sales method (including the 30 percent initial apportionment).

9. This statement, along with much of the subsequent analysis, abstracts from the ability of firms to carry excess foreign tax credits backward two years and forward five years. Firms that can exploit carryforwards or carrybacks may (depending on specific circumstances) face intermediate incentives between those of deficit credit and excess credit firms. 
The Economic Recovery Tax Act in 1981 changed these rules by permitting U.S. firms to allocate 100 percent of the expense of R\&D performed in the United States against U.S. taxable income. This change was intended to be temporary (lasting two years), in order to offer strong R\&D incentives while affording Congress the opportunity to rethink its R\&D policy. At the end of that time, the U.S. Department of the Treasury produced a study (1983) concluding that the tax change offered a small R\&D incentive to U.S. firms, and that it was desirable on that basis. ${ }^{10}$ In 1984 and 1985 Congress extended the temporary change permitting 100 percent deductibility of U.S. R\&D expenses against U.S. income, so these rules remained in place until the end of the 1986 tax year.

The Tax Reform Act of 1986 removed the 100 percent deductibility of U.S. R\&D expenses, replacing it with a new (and again temporary) system of R\&D expense allocation. ${ }^{11}$ Under TRA 1986, 50 percent of U.S. R\&D expense (other than $R \& D$ to meet regulations, which was 100 percent allocated to domestic source) was allocated to domestic source, with the remaining 50 percent allocated on the basis of sales or of income, at the taxpayer's choice. No limit was imposed on the degree to which allocation on the basis of gross income could reduce foreign allocation relative to the sales method. These rules, it turned out, were in effect only for 1987.

The Technical and Miscellaneous Revenue Act of 1988 changed the R\&D expense allocation rules for the first part of 1988. For the first four months of the year, firms were permitted to allocate 64 percent of U.S. $\mathrm{R} \& \mathrm{D}$ expense against U.S. domestic income, with the remaining 36 percent allocated between foreign and domestic sources on the basis of either sales or income (at the taxpayer's choice). The 1988 Act further provided that if the 36 percent were allocated on the basis of income, then the R\&D allocation against foreign income must equal at least 30 percent of the foreign allocation that would have been produced by the sales method. For the remaining eight months of the year, taxpayers were required to use the allocation method described in section 1.861-8 as of 1977 (and described previously).

The Omnibus Budget Reconciliation Act of 1989 again changed the $\mathrm{R} \& \mathrm{D}$ allocation rules, this time reintroducing the same rules that had applied for the first four months of 1988. The Omnibus Budget Reconciliation Act of 1990 and the Tax Extension Act of 1991 extended this treat-

10. The U.S. Department of the Treasury study (1983) based its conclusions on a range of assumed elasticities of $\mathrm{R} \& \mathrm{D}$ with respect to price changes; there was no attempt made to ascertain how firms responded to the changes introduced in 1981.

11. The Tax Reform Act of 1986 also introduced a number of other changes relevant to $\mathrm{R} \& \mathrm{D}$ investment decisions, including reducing the statutory corporate tax rate from 46 percent (the tax rate from 1979 to 1986) to 40 percent in 1987 and 34 percent for 1988 and subsequent years. The 1986 Act also removed a number of investment incentives, such as accelerated depreciation of capital assets and the investment tax credit for new equipment purchases. 
ment of R\&D expenses until a date that depends on a taxpayer's choice of fiscal year, but in no case later than 1 August 1992. Consequently, 64 percent of domestically performed R\&D in 1989-1992 could be allocated against domestic income, with the remaining 36 percent allocated on the basis of either sales or income (although use of the income method could not reduce foreign source allocation to less than 30 percent of the foreign source allocation that would have been produced by the sales method).

The expiration of the R\&D expense allocation legislation in the summer of 1992 motivated an extensive reconsideration of the issue of the appropriate tax treatment of R\&D expenditures by MNCs. In June 1992, the U.S. Department of the Treasury temporarily suspended its section 1.861-8 allocation rules (the 1977 regulations), replacing them with an eighteenmonth moratorium during which taxpayers could continue to use the system embodied in the legislation covering the years 1989-1992 (64 percent place-of-performance allocation, with the remaining deductions allocated on the basis of sales). The idea was that the Treasury would reexamine its section 1.861-8 regulations during the eighteen-month period. The rationale for the moratorium was "to provide taxpayers with transition relief and to minimize audit controversy and facilitate business planning during the conduct of the regulatory review." ${ }^{12}$ Some contemporaneous observers noted that the extension of the R\&D allocation rules through Treasury moratorium instead of Congressional legislation made the rules less costly from the standpoint of federal budget targets, because regulatory changes are exempt from the budget agreement limits. What role, if any, such considerations played in the decision to suspend the section 1.861-8 rules is not clear. In any case, the Treasury moratorium did not run its full course, being supplanted in 1993 by new legislation.

President Clinton's budget proposal of February 1993 recommended a major change in the allocation of $\mathrm{R} \& \mathrm{D}$ expenditures and the treatment of royalty receipts by U.S.-based MNCs. The president proposed that U.S. firms deduct 100 percent of their U.S. R\&D expenditures against U.S. income, but that the same firms no longer be permitted to use foreign tax credits generated by their active foreign operations to reduce U.S. tax liabilities on royalty income from foreign sources. Instead, firms would be required to allocate foreign source royalty income to the passive basket in determining their foreign tax credit limits. The idea behind the change was to limit severely the ability of U.S. firms to use excess foreign tax credits to wipe out their U.S. tax liabilities on foreign source royalty income. Very few firms have excess foreign tax credits in the passive basket. Consequently, the overall effect of the proposal would have been to raise the deductions that firms with excess foreign tax credits receive for $R \& D$ performed in the United States, but to include - as income fully taxed by

12. U.S. Congress, Joint Committee on Taxation $(1993,55)$. 
the United States - the royalties they receive from foreign sources. Congress chose not to include this proposal in the legislation passed in August 1993.

Instead, the Omnibus Budget Reconciliation Act of 1993 (OBRA 93) continued the pattern of allowing U.S.-based MNCs to deduct only a fraction of their U.S. R\&D expenses against U.S. income, and, at the same time, permitted firms to use excess foreign tax credits to eliminate U.S. tax liabilities on foreign source royalty income. OBRA 93 permitted firms to allocate 50 percent of U.S.-based R\&D expenses to domestic source, with the remaining 50 percent allocated between domestic and foreign source, based either on sales or on income, at the taxpayer's option (subject to the restriction that income-based allocation not reduce foreign source allocation to less than 30 percent of that produced by the sales method). The allocation rules under OBRA 93 were temporary, expiring one year after they took effect. As in earlier years, many observers attributed the temporary nature of the allocation rules to the mechanics of compliance with federal budget targets: If Congress were to pass permanent legislation covering the $\mathrm{R} \& \mathrm{D}$ allocation rules, then the cost, to the current-year budget, of any treatment more generous than the 1977 regulations, must include costs incurred in future years. By instead passing temporary legislation, Congress incurs budgetary costs only for the current year. Of course, budgetary costs need not bear any relation to the economic consequences of permanent legislation covering the allocation of R\&D expenses. ${ }^{13}$

During 1995 the Treasury reconsidered the appropriateness of its 1977 R\&D expense regulations. Based on newer analysis (U.S. Department of the Treasury 1995), the regulations were amended roughly along the lines of recent legislative developments. Specifically, the 1995 regulations permit firms to select one of two allocation methods: one in which firms allocate 50 percent of U.S.-based R\&D expenses to domestic source, with the remaining 50 percent allocated between domestic and foreign source based on sales; and a second in which firms allocate 25 percent of U.S.-based $\mathrm{R} \& \mathrm{D}$ expenses to domestic source, with the remaining 75 percent allocated between domestic and foreign source based on gross income. Under these regulations, income-based allocation is not permitted to reduce foreign source allocation to less than 50 percent of that produced by the sales method. The new regulations amend the previous rules in certain, more minor, ways as well. ${ }^{14}$ Owing to the expiration of the OBRA 93 R\&D allo-

13. Some have strong feelings that permanent legislation creates a more predictable environment for businesses, thereby making the United States a more attractive location for R\&D. Turro $(1993,436)$ quotes one tax practitioner, who describes Congress's decision to make the OBRA 93 R\&D allocation rules temporary an "absurd tax policy decision."

14. Specifically, firms are required to make their elections permanent, so it is not possible to use the sales method in one year and the income method in the next. In addition, the new regulations specify that firms allocate R\&D expenses based on three-digit SIC activities, rather than the two-digit SIC activities provided in the previous regulations. 
cation rules, the 1995 Treasury regulations now govern the allocation of U.S. R\&D expenses. ${ }^{15}$

\subsection{Framework for Analysis}

Changes in the U.S. tax treatment of R\&D expenses affect some firms more than others, due to differences in excess foreign tax credit status and in the extent to which sales and income have foreign sources. Consequently, these changes can be used to identify differences between firms in costs of performing R\&D in the United States in years before and after tax changes. The idea behind the empirical work that follows is to draw appropriate inferences from correlations between tax-driven cost changes and subsequent propensities to take out patents on the basis of U.S. and foreign research activities.

\subsubsection{A Model}

It is useful to distinguish three types of R\&D undertaken by MNCs. The first type is R\&D performed in the United States and intended to produce innovative output for the U.S. market. The second type is R\&D performed in the United States and intended to generate foreign sales. The third type is R\&D performed abroad. Tax incentives differ for each of these types, and as a result, the incentives that firms face to undertake $\mathrm{R} \& \mathrm{D}$ in domestic and foreign locations will differ. Of course, to a certain degree these distinctions may be more pronounced ex post than they are ex ante, because, in the early stages of industrial research, the location of ultimate sales may be more than a little bit uncertain. For the purpose of this analysis, firms are assumed to be able to distinguish the ultimate location of the uses of their innovative output at the time that they perform the initial R\&D.

The R\&D expense allocation rules imply that MNCs performing R\&D in the United States are unable to deduct all of their R\&D expenses in years after 1986. Instead, they can deduct a fraction $\alpha$ of such expenses, in which the value of $\alpha$ depends on the firm's foreign tax credit status, its ratio of foreign to domestic sales, and the tax rules in place at the time. U.S. tax rules in effect between 1981 and 1986 imply that $\alpha=1$, whereas those in effect after 1986 imply that $1 \geq \alpha \geq 0$.

A U.S. firm that contemplates committing funds to an $R \& D$ project that is expected to generate innovative output, and therefore sales in the domestic market, maximizes

$$
\pi_{i}=Q\left(R_{i}, \theta_{\mathrm{i}}\right)(1-\tau)-R_{i}\left(1-\alpha_{i} \tau\right)
$$

15. It is noteworthy that the 1995 revisions to the $R \& D$ cost allocation regulations were not costly from the standpoint of federal budget targets because regulatory changes are not budgeted. 
in which $\pi_{i}$ denotes firm $i$ 's after-tax profits, $R_{i}$ is firm $i$ 's expenditures on $\mathrm{R} \& \mathrm{D}, Q(\cdot)$ is net sales generated by firm $i$ 's $\mathrm{R} \& \mathrm{D}$ activity, $\alpha_{i}$ is the fraction of firm $i$ 's R\&D expenses that are deductible for tax purposes, and $\tau$ is the statutory tax rate. The variable $\theta_{i}$ is an unobservable parameter (assumed to be known to firms) that affects the productivity of firm $i$ 's research activity and thereby influences its desired R\&D spending. The function $Q(\cdot)$ is assumed to be twice continuously differentiable and concave in R. The first-order condition corresponding to an interior maximum of (1) is $\partial \pi_{i} / \partial R_{i}=0$, which implies

$$
\frac{\partial Q\left(R_{i}, \theta_{i}\right)}{\partial R_{i}}=\frac{1-\alpha_{i} \tau}{1-\tau} .
$$

Equation (2) expresses the simple point that reduced deductibility of domestic R\&D expenses, which is captured by lower values of $\alpha_{i}$, are associated with higher required marginal products of $R \& D$ expenditures by profit-maximizing firms. Because the function $Q(\cdot)$ is assumed to exhibit decreasing returns to $R$, it follows that lower values of $\alpha_{i}$ reduce desired spending on $\mathrm{R} \& \mathrm{D}$.

The incentives facing a U.S. multinational performing R\&D in the United States for use abroad are potentially quite different. Returns to the innovating firm come in the form of foreign source royalties that are effectively untaxed by the United States if the firm has excess foreign tax credits, and that are fully taxed otherwise. Denoting firm i's R\&D undertaken for this purpose by $R_{i}^{*}$, and the relevant sales function by $Q^{*}\left(R_{i}^{*}\right.$, $\left.\theta_{i}\right){ }^{16}$ the firm's profits from this source $\left(\pi_{i}^{*}\right)$ equal

$$
\pi_{i}^{*}=Q^{*}\left(R_{i}^{*}, \theta_{i}\right)\left(1-\beta_{i} \tau\right)-R_{i}^{*}\left(1-\alpha_{i} \tau\right),
$$

in which $\beta_{i}$ reflects the extent to which firm $i$ 's foreign source royalties are taxed, so that $\beta_{i}=0$ for firms with excess foreign tax credits and $\beta_{i}=1$ for firms with deficit foreign tax credits.

The first-order condition corresponding to an interior maximum of (3) with respect to $R_{i}^{*}$ is $\partial \pi_{i}^{*} / \partial R_{i}^{*}=0$, implying

$$
\frac{\partial Q^{*}\left(R_{i}^{*}, \theta_{i}\right)}{\partial R_{i}^{*}}=\frac{1-\alpha_{i} \tau}{1-\beta_{i} \tau} .
$$

Equation (4) expresses in a simple way that the incentive to perform R\&D in the United States for use abroad is a function of the deductibility of $R \& D$ expenses as well as of the tax treatment of foreign source royalty

16. Strictly speaking, it is necessary for the analysis that follows to include as an argument of the $\mathrm{Q}^{*}(\cdot)$ function $\mathrm{R} \& \mathrm{D}$ undertaken by foreign affiliates; this argument is omitted, because including it complicates the notation without changing the interpretation of the results. 
receipts. Assuming the $Q^{*}(\cdot)$ function to exhibit decreasing returns to $R^{*}$, it follows that the desired level of $R^{*}$ is an increasing function of $\alpha$ and a decreasing function of $\beta$.

The third type of R\&D that MNCs undertake is foreign R\&D. The foreign innovative activity of U.S. multinationals is a decreasing function of R\&D performed in the United States and intended for foreign use $\left(R^{*}\right)$ if foreign and domestic research are substitutes, and an increasing function of $R^{*}$ if they are complements. ${ }^{17}$ Because $R_{i}^{*}$ is not directly observable, it is necessary to infer its value from the tax incentives that firm $i$ faces. This inference is greatly complicated by the likely importance of firm-specific technology shocks. Firms differ greatly in their abilities and willingness to patent new technologies, and these differences may change over time. It is convenient to introduce the variable $\phi_{i t}$, which denotes a firm-specific shock to the patenting proclivity of firm $i$ in period $t$. The firm-specific shock $\phi_{i t}$ differs from $\theta_{i t}$, in that $\theta_{i t}$ affects the marginal product of additional R\&D spending, while $\phi_{i t}$ affects the proclivity to obtain patents conditional on research activity.

It is helpful to define foreign and domestic patenting functions:

$$
\begin{aligned}
P_{i t}^{*} & =\psi^{*}\left(R_{i t}^{f}, \phi_{i t}\right), \\
P_{i t} & =\psi\left(R_{i t}, \phi_{i t}\right),
\end{aligned}
$$

in which $R_{i t}^{f}$ is the foreign $\mathrm{R} \& \mathrm{D}$ spending of firm $i$ in year $t, P_{i t}^{*}$ is the number of foreign patents taken out by firm $i$ in year $t$, and $P_{i t}$ is the corresponding number of domestic patents. ${ }^{18}$

From equation (4) it is clear that the after-tax cost of domestic R\&D directed at producing sales in foreign markets is a function of the firm's domestic tax situation. The extent, therefore, to which these domestic tax considerations affect $R_{i t}^{f}$ (and thereby affect $P_{i t}^{*}$ ) depends on the complementarity or substitutability of foreign and domestic technology. The firm's derived demand for foreign R\&D can be written

$$
R_{i t}^{f}=g^{*}\left\{\left[\frac{\left(1-\alpha_{i t} \tau_{t}\right)}{\left(1-\beta_{i t} \tau_{t}\right)}\right], \theta_{i t}\right\},
$$

17. This discussion takes the returns to foreign $R \& D$ to be unaffected by domestic $R \& D$ intended for the domestic market. This is a reasonable assumption, given the very limited domestic use of technology produced by foreign affiliates, as reflected by royalty payments reported in table 8.1.

18. It is noteworthy that this specification assumes that any technology spillovers between domestic and foreign innovation are fully credited to proper sources and therefore reflected in royalty payments. The functional forms of equations (5a) and (5b) also require that patenting be affected only by R\&D performed contemporaneously, a testable proposition examined in the next section. 
in which the first argument of the $g^{*}$ function is simply the after-tax cost of performing $\mathrm{R} \& \mathrm{D}$ at home to generate sales abroad, and other considerations, such as firm and economy characteristics in year $t$, are captured by $\theta_{i t}$.

Combining equations (5a) and (6) yields a function that expresses foreign patenting as it is affected by the price of domestic R\&D:

$$
P_{i t}^{*}=h^{*}\left\{\left[\frac{\left(1-\alpha_{i t} \tau_{t}\right)}{\left(1-\beta_{i t} \tau_{t}\right)}\right], \theta_{i t}, \phi_{i t}\right\} .
$$

By a similar reasoning, the demand for domestic $\mathrm{R} \& \mathrm{D}$ directed at producing sales in the domestic market is a function of the implied after-tax cost indicated by equation (2):

$$
R_{i t}=g\left\{\left[\frac{\left(1-\alpha_{i t} \tau_{t}\right)}{\left(1-\tau_{t}\right)}\right], \theta_{i t}\right\},
$$

which, combined with equation (5b), implies

$$
P_{i t}=h\left\{\left[\frac{\left(1-\alpha_{i t} \tau_{t}\right)}{\left(1-\tau_{t}\right)}\right], \theta_{i t}, \phi_{i t}\right\},
$$

in which the $h(\cdot)$ function expresses domestic patenting as a function of the price of domestic $\mathrm{R} \& \mathrm{D}$ as well as firm-specific shocks.

Linearizing the effect of $\theta$ and $\phi$ yields

$$
P_{i t}^{*}=f^{*}\left[\frac{\left(1-\alpha_{i t} \tau_{t}\right)}{\left(1-\beta_{i t} \tau_{t}\right)}\right]+c^{*}\left(\theta_{i t}+\phi_{i t}\right),
$$

and

$$
P_{i t}=f\left[\frac{\left(1-\alpha_{i t} \tau_{t}\right)}{\left(1-\tau_{t}\right)}\right]+c\left(\theta_{i t}+\phi_{i t}\right),
$$

in which $c^{*}$ and $c$ are constants that reflect the impact of firm-specific shocks on foreign and domestic patenting.

Combining equations (10) and (11), and taking first differences, yields

$$
\begin{aligned}
P_{i t}^{*}-P_{i t-1}^{*} & =\delta_{1 i t}-\left(\frac{c^{*}}{c}\right) \delta_{2 i t}+\left(\frac{c^{*}}{c}\right)\left(P_{i t}-P_{i t-1}\right), \\
\delta_{1 i t} & \equiv f^{*}\left[\frac{\left(1-\alpha_{i t} \tau_{t}\right)}{\left(1-\beta_{i t} \tau_{t}\right)}\right]-f *\left[\frac{\left(1-\alpha_{i t-1} \tau_{t-1}\right)}{\left(1-\beta_{i t-1} \tau_{t-1}\right)}\right], \\
\delta_{2 i t} & \equiv f\left[\frac{\left(1-\alpha_{i t} \tau_{t}\right)}{\left(1-\tau_{t}\right)}\right]-f\left[\frac{\left(1-\alpha_{i t-1} \tau_{t-1}\right)}{\left(1-\tau_{t-1}\right)}\right] .
\end{aligned}
$$


Equation (12) expresses the change in foreign patenting as a function of three variables: the change in home-country tax incentives for home R\&D directed at foreign markets, the change in tax incentives for home $R \& D$ directed at domestic markets, and the change in domestic patenting. Estimates of the propensity to develop foreign patents as a function of these variables implicitly estimate the degree of complementarity or substitutability of foreign and domestic $\mathrm{R} \& \mathrm{D}$, because this connection is embedded in the $f^{*}(\cdot)$ function. It is this specification that provides the framework used in the empirical analysis.

\subsubsection{Data}

The empirical work that follows analyzes the behavior of publicly traded firms whose annual report information is collected by Standard and Poors Compustat Service. Starting from a universe of somewhat more than 7,500 companies, firms are included in the sample if they are multinationals incorporated in the United States, and if their reported foreign assets equal 1 percent or more of reported total assets for each year during 1986-1990. This criterion is satisfied by 422 firms.

Foreign tax rate information is central to the analysis, because the hypothesis that firms maximize after-tax profits implies that deficit foreign tax credit firms will react very differently than excess foreign tax credit firms to the changes introduced by TRA 1986. Compustat reports foreign pretax incomes and foreign taxes paid by the firms in the sample, from which it is possible to use simple division to obtain an estimate of effective foreign tax rates. ${ }^{19}$ These average foreign tax rates for firms in 1985 form the basis of the tax calculations that follow. Data for 1985 are used because this was the last full year before passage of TRA 1986, which introduced incentives to relocate foreign operations and tax liabilities. Average foreign tax rates are truncated at 0 and 100 percent for purposes of this construction.

During the 1983-1986 period, U.S. tax law permitted U.S. firms to deduct 100 percent of their domestic R\&D expenses against domestic taxable income. In the years after 1986, deductibility is based on excess foreign tax credit status and on shares of total sales in foreign markets. For the purposes of constructing regression variables, $\alpha_{i t}$ is assigned a value of 1 for all firms until 1986. In the period after 1986, firms are assigned $\alpha_{i t}=$ 1 if the 1985 foreign average tax rate is below the (year $t$ ) U.S. statutory tax rate; otherwise $\alpha_{i t}=[1-0.36$ (foreign sales fraction)], corresponding

19. Average foreign tax rates are used in place of actual foreign tax credit status (i.e., excess or deficit credit) for two reasons. The first is that actual foreign tax status is endogenous to a host of decision variables related to the financing, investment, repatriation, transfer pricing, and other activities of MNCs. Although average foreign tax rates are, by the same reasoning, also endogenous, the endogeneity problem is generally regarded to be more severe with excess foreign tax credit status than it is with average foreign tax rates. The second reason is that tax return data at the firm level are unavailable, so the actual foreign tax credit situations of firms in the sample cannot be determined. 
to the expense allocation rules in place in 1991. Because the value of $\beta_{i t}$ depends critically on foreign tax credit status about which only imprecise information is available, a more continuous tax specification is used in defining $\beta_{i t}: \beta_{i t}$ is defined to equal 1 minus the average foreign tax rate a firm faced in 1985.

To determine the international distribution of patenting, the 422 sample firms were matched to the database of U.S. patents created by NBER and Case Western Reserve University. ${ }^{20}$ The NBER/CWRU database contains all patents granted by the U.S. government between 1963 and 1996. This database, based on the public patent records, identifies for every patent the inventors, the geographic location of the inventors, and a corporate assignee (if any) to whom the patent right is transferred by the inventor. ${ }^{21}$ To use these data for the current purpose, it was necessary to identify all U.S. patents that were taken out by the sample firms or their affiliates, as well as the countries in which the patents originated.

The task of identifying the patents of the sample firms is complicated by two problems. First, the patent office does not utilize an external code or identifier that permits patenting assignees to be linked electronically to data such as provided by Compustat. Rather, assignees are indicated by name, and the spelling and punctuation of the names are not completely standardized - there may be patent records for "IBM" and others for "I.B.M." Secondly, and more fundamentally, companies choose the corporate entity to which the patent will be assigned, which could be a subsidiary or an affiliated company rather than the parent company. As described further in Hall, Jaffe, and Trajtenberg (2000), the NBER/CWRU database contains a match between the corporate assignees in the patent office data and Compustat firms; the match attempts to deal with both of these problems. First, spelling and punctuation variations were standardized by removing all spaces, punctuation, generic words (e.g., "Inc." and "Co.") and searching for apparent multiple versions of the same entities based on these compressed names. All potential matches of this sort were checked by hand to ensure that they were real. Second, approximately 30,000 subsidiaries and affiliates of the Compustat universe, as indicated in the 1998 Who Owns Whom Directory of Corporate Affiliations (Dun \& Bradstreet Ltd. 1989), were matched to the patent database to identify patents taken out by these affiliates, and these affiliated patents were assigned to the parent companies for the purpose of this paper.

20. For more information on this database, see the description in Hall, Jaffe, and Trajtenberg (2000).

21. Patents must be taken out by the individual or individuals who created the invention. About three-fourths of all patents are assigned, at the time of the patent application, to an institution, typically the inventors' employer.

The NBER/CWRU database contains additional information not used in this paper, including a technological classification of the patent and information about citations between patents. See Jaffe and Trajtenberg (1999) and Hall, Jaffe, and Trajtenberg (2000). 
The geographic location of the patent is based on the location of the first inventor listed on the patent. ${ }^{22}$ The inventor locations in the patent data are domestic residences (not citizenships or nationalities) of inventors as indicated on patent applications. Hence, it is reasonable to expect that a patent based on an invention from an IBM laboratory in Japan would be coded as a "Japanese" patent. The patent might be assigned to IBM, Inc., or it might be assigned to an affiliate or subsidiary organized in Japan. Either way, in principle, it would be treated as if it were an IBM patent, so long as the Who Owns Whom directory includes the ownership link. Certainly, it is possible for some subsidiaries and affiliates to be omitted in this classification, which would mean that the foreign patent counts of their parent firms are systematically biased downward. Further, to the extent that the creation of such foreign affiliates or the assignment of patents to them has changed over time, the change in foreign patents for these firms might be systematically biased. There is no obvious reason, however, that such an undercount of foreign patents would be correlated with the other variables of interest.

For the purpose of estimation the data are combined to form two observations for each firm, one corresponding to the 1983-1986 period, and a second corresponding to the 1988-1991 period. Foreign and domestic patents are summed over the four years that constitute each period. The specification of equation (12) that is then estimated is one in which the dependent variable is the difference between the number of foreign patents taken during the 1988-1991 period and the number taken during the 1983-1986 period. Similarly, the change-in-domestic-patents variable that appears on the right side of equation (12) equals the difference between the number of domestic patents taken during the 1988-1991 period and the number taken during the 1983-1986 period.

Table 8.2 presents country-level information on foreign patents by firms in the sample, along with other indicators of activity by the foreign affiliates of U.S. multinationals. Foreign patenting is concentrated in a relatively small number of technologically advanced countries, which is not surprising; nor is it surprising that R\&D spending by the foreign affiliates of U.S. multinationals is concentrated in roughly the same countries. Indeed, the five foreign countries (the United Kingdom, Japan, Germany, Canada, and France) with the most patents attributed to resident inventors over the period 1988-1991 lead all others in R\&D spending by U.S. multinationals in 1989. To be sure, there is important variation among countries, and most importantly, the vast majority of U.S. patents taken out by sample firms have inventors that are residents of the United States. The

22. Jaffe, Trajtenberg, and Henderson (1993) investigated the extent of geographic dispersion among the inventors on a given patent. They found that all inventors on a given patent listed the same country of residence on 98 percent of all patents (including those with a single inventor). 


\begin{tabular}{|c|c|c|c|c|c|}
\hline & $\begin{array}{c}\text { Patents } \\
\text { 1983-1986 }\end{array}$ & $\begin{array}{c}\text { Patents } \\
1988-1991\end{array}$ & $\begin{array}{l}\text { Net PPE } \\
1989\end{array}$ & $\begin{array}{l}\text { Sales } \\
1989\end{array}$ & $\begin{array}{c}\text { R\&D } \\
\text { Spending } 1989\end{array}$ \\
\hline Australia & 14 & 17 & 12,113 & 37,745 & 191 \\
\hline Austria & 2 & 1 & 919 & 5,550 & 16 \\
\hline Bahamas & 0 & 1 & 616 & 1,529 & $*$ \\
\hline Belgium & 109 & 106 & 4,811 & 30,085 & 317 \\
\hline Brazil & 4 & 6 & 9,223 & 30,588 & 90 \\
\hline Canada & 152 & 305 & 63,636 & 173,251 & 914 \\
\hline Chile & 1 & 1 & 718 & 1,981 & 1 \\
\hline Colombia & 0 & 1 & 1,959 & 3,895 & 2 \\
\hline Denmark & 3 & 10 & 923 & 4,119 & $\mathrm{~d}$ \\
\hline Dominican Republic & 0 & 0 & 281 & 578 & $*$ \\
\hline Ecuador & 1 & 0 & 196 & 578 & $*$ \\
\hline Egypt & 1 & 0 & 1,313 & 1,871 & $*$ \\
\hline France & 148 & 214 & 11,093 & 70,761 & 545 \\
\hline Germany & 360 & 418 & 21,066 & 106,366 & 1,496 \\
\hline Greece & 3 & 1 & 174 & 1,932 & 1 \\
\hline Guatemala & 1 & 0 & 133 & 672 & $*$ \\
\hline Hong Kong & 4 & 7 & 3,174 & 16,408 & 9 \\
\hline India & 1 & 10 & 76 & 323 & 2 \\
\hline Indonesia & 1 & 0 & 4,644 & 6,120 & 2 \\
\hline Ireland & 7 & 37 & 1,874 & 11,415 & 134 \\
\hline Israel & 11 & 53 & 326 & 1,042 & 29 \\
\hline Italy & 35 & 50 & 6,386 & 45,265 & 294 \\
\hline Japan & 174 & 483 & 7,830 & 58,420 & 488 \\
\hline Luxembourg & 26 & 21 & 633 & 1,443 & $\mathrm{~d}$ \\
\hline Malaysia & 3 & 10 & 2,212 & 5,419 & 3 \\
\hline Mexico & 1 & 1 & 3,929 & 16,437 & 37 \\
\hline Netherlands & 52 & 84 & 8,182 & 45,408 & 360 \\
\hline New Zealand & 1 & 1 & 775 & 3,153 & 4 \\
\hline Nigeria & 0 & 0 & 706 & 2,250 & $*$ \\
\hline Norway & 4 & 4 & 5,865 & 7,616 & 27 \\
\hline Philippines & 2 & 2 & 531 & 2,905 & 5 \\
\hline Singapore & 1 & 26 & 2,153 & 15,102 & 25 \\
\hline South Africa & 2 & 4 & 449 & 2,653 & 9 \\
\hline South Korea & 6 & 4 & 641 & 2,463 & 5 \\
\hline Spain & 6 & 8 & 4,514 & 23,712 & 115 \\
\hline Sweden & 13 & 12 & 732 & 7,703 & 33 \\
\hline Switzerland & 93 & 88 & 1,977 & 36,231 & 67 \\
\hline Taiwan & 0 & 4 & 1,047 & 6,773 & 23 \\
\hline United Kingdom & 540 & 749 & 42,418 & 167,186 & 1,673 \\
\hline Venezuela & 0 & 3 & 461 & 2,677 & 9 \\
\hline United States & 28,516 & 39,143 & & & \\
\hline
\end{tabular}

Note: Columns (1) and (2) report total numbers of U.S. patents granted to the 378 U.S. firms in the sample and assigned to inventors located in designated countries. Column (3) reports aggregate values (in \$ millions) of the local property, plant, and equipment of majority-owned nonbank affiliates of nonbank U.S. parent firms in 1989. Column (4) reports aggregate sales (in \$ millions) of majorityowned nonbank affiliates of nonbank U.S. parent firms in 1989. Column (5) reports aggregate R\&D expenditures (in \$ millions) on behalf of majority-owned nonbank affiliates of nonbank U.S. parent firms in 1989. $\mathrm{d}=$ data suppressed to protect the identity of individual survey respondents. ${ }^{*}=\mathrm{R} \& \mathrm{D}$ spending of less than $\$ 500,000$. Data reported in columns (3)-(5) are drawn from U.S. Department of Commerce (1992). 
Table 8.3

R\&D Activity and Patenting Behavior

\begin{tabular}{lcccc}
\hline & \multicolumn{2}{c}{$\ln$ (total patents, } & \multicolumn{2}{c}{$\ln (1+$ total patents, } \\
& \multicolumn{2}{c}{$1982-1985)$} & $-1985)$ \\
\hline Constant & 0.8714 & -0.9037 & -1.0570 & -1.8438 \\
& $(0.1478)$ & $(0.3452)$ & $(0.1797)$ & $(0.3429)$ \\
$\ln (\mathrm{R} \& \mathrm{D}, 1986)$ & 0.8376 & 0.4726 & 0.7317 & 0.5569 \\
& $(0.0371)$ & $(0.0735)$ & $(0.0369)$ & $(0.0740)$ \\
Patents dummy & & & 3.1103 & 3.0377 \\
& & & $(0.2063)$ & $(0.2178)$ \\
$\ln$ (Assets, 1986) & & 0.4470 & & 0.2151 \\
& & $(0.0787)$ & & $(0.0857)$ \\
$R^{2}$ & .690 & .728 & .782 & .788 \\
$N$ & 231 & 231 & 292 & 292 \\
\hline
\end{tabular}

Note: The table reports estimated coefficients from ordinary least squares (OLS) regressions. The dependent variable in the regressions reported in columns (1) and (2) is the log of the number of new patents (domestic plus foreign) taken out between 1982 and 1985 . Observations are included in the samples analyzed in these regressions only if they have nonzero and nonmissing patent and $\mathrm{R} \& \mathrm{D}$ data. The dependent variable in the regressions reported in columns (3) and (4) is the log of 1 plus the number of new patents (domestic plus foreign) taken out between 1982 and 1985. Observations are included in the samples analyzed in these regressions only if they have nonzero and nonmissing R\&D data. " $\ln (\mathrm{R} \& \mathrm{D}, 1986)$ " is the $\log$ of total R\&D expenditures in 1986. "Patents dummy" is a dummy variable that equals 1 if a firm took out nonzero patents between 1982 and 1985, and equals 0 otherwise. "ln(Assets, 1986)" is the log of total firm assets in 1986. Heteroskedasticity-consistent standard errors are in parentheses.

foreign data presented in table 8.2 , however, serve to confirm the reasonableness of the patent attribution method on which is based the empirical work that follows.

\subsection{Results}

As a prelude to estimating the model implied by equation (12), the regressions reported in table 8.3 look simply at the firm-level relationship between R\&D and patents as it is evident in the data. Columns (1) and (2) of table 8.3 present estimates in which the dependent variable is the log of total (worldwide) firm patents over the 1982-1985 period, and the independent variables include the log of R\&D spending in 1986 and $\log$ of total firm assets in 1986. The sample analyzed in these regressions is limited to firms with nonzero patents over 1982-1985, and those with positive R\&D spending and total assets in 1986.

Consistent with other work, ${ }^{23}$ the results indicate a strong correlation between patenting and $R \& D$ activity, one that is not simply a function of firm size (as measured by assets). The regression of log of patents on log R\&D (reported in column (1)) shows slightly less than constant returns of patents to $R \& D$, although this result is somewhat sensitive to how the 
observations with no patents are treated. When log of total assets is added to the regression, as it is in the regression reported in column (2), log assets absorbs part of the explanatory power of $\log \mathrm{R} \& \mathrm{D}$, but the results continue to imply a patent production function with approximately constant returns to scale. Columns (3) and (4) of table 8.3 report regressions using a larger sample of firms that includes those with no patents during the 1982-1985 period. The dependent variable in these regressions is now the $\log$ of 1 plus patents, and the right-hand side variables now include a dummy variable that takes the value 1 if a firm has nonzero patents over this time period. The results reported in columns (3) and (4) are qualitatively similar to those reported in columns (1) and (2), in that a strong positive relationship between patents and $R \& D$ spending exhibits decreasing returns.

The consistency of the firm-level patent data with country and firm characteristics (as evidenced in tables 8.2 and 8.3) offers the prospect of informative estimation of variants of equation (12) using these data. Table 8.4 presents means and standard deviations of the regression variables, and the initial regression results are presented in table 8.5. The specification estimated in these regressions is

$$
\begin{aligned}
P_{i t}^{*}-P_{i t-1}^{*} & =\beta_{1}\left(P_{i t}-P_{i t-1}\right)+\beta_{2} \alpha_{i t}+\beta_{3} \lambda_{i t}+\beta_{4} X_{i t}+\varepsilon_{i t}, \\
\lambda_{i t} & \equiv\left[\frac{\left(1-\alpha_{i t} \tau_{t}\right)}{\left(1-\beta_{i t} \tau_{t}\right)}\right]-\left[\frac{\left(1-\alpha_{i t-1} \tau_{t-1}\right)}{\left(1-\beta_{i t-1} \tau_{t-1}\right)}\right] .
\end{aligned}
$$

Comparing equations (13) and (12), it follows that the regression coefficients can be interpreted as $\beta_{1}=\left(c^{*} / c\right), \beta_{2}$ equals the product of $\left(c^{*} / c\right)$ and a linearization of the $f(\cdot)$ function, and $\beta_{3}$ captures a different linearization of the $f^{*}(\cdot)$ function. The reason that the first difference of the $f(\cdot)$ function may be represented in equation (13) simply by $\alpha_{i t}$ is that all firms were entitled to deduct their full R\&D expenses in the period before 1986, and all faced the same statutory taxes after 1986, so that this term differs between firms only in $\alpha_{i t}$. The variable $X_{i t}$ represents firm-specific characteristics (including a constant term).

Column (1) of table 8.5 reports estimates of equation (13) without including firm-specific characteristics (other than constants). The estimated coefficients are consistent with the evidence reported in other tables and with a generally complementary relationship between domestic and foreign innovative activity. The estimated value of $\beta_{1}$ is approximately 0.06 , which means that shocks to domestic patenting translate rather little into changes in foreign patents - reflecting the much larger share of U.S. inventors than foreign inventors among the patents taken out by U.S. firms. The estimated value of $\beta_{2}$ is positive but not significant, although this is not of great consequence because $\alpha_{i t}$ is included in equation (13) merely in order to control for changes in domestic patenting due to tax changes rather than firm-specific shocks. 


\begin{tabular}{|c|c|c|c|}
\hline Variable & Mean & $\begin{array}{l}\text { Standard } \\
\text { Deviation }\end{array}$ & $N$ \\
\hline \multicolumn{4}{|c|}{ R\&D Sample (table 8.3) } \\
\hline $\ln ($ total patents, $1982-85)$ & 3.5225 & 1.9805 & 231 \\
\hline $\ln (1+$ total patents, $1982-85)$ & 3.5571 & 2.4662 & 292 \\
\hline $\ln (\mathrm{R} \& \mathrm{D}, 1986)$ & 2.8121 & 2.0368 & 292 \\
\hline Patents dummy & 0.8219 & 0.3832 & 292 \\
\hline $\ln$ (Assets, 1986) & 6.5559 & 1.8240 & 231 \\
\hline \multicolumn{4}{|c|}{ Foreign Patents Sample (tables 8.5 and 8.6) } \\
\hline Change in foreign patents & 3.0317 & 14.8684 & 378 \\
\hline Change in domestic patents & 35.2116 & 178.7609 & 378 \\
\hline R\&D expense deductibility, 1991 & 0.8806 & 0.1315 & 378 \\
\hline Change in R\&D tax incentives (foreign) & -0.1126 & 0.0713 & 378 \\
\hline Percent foreign sales, 1991 & 0.3242 & 0.1946 & 378 \\
\hline First-period foreign patents & 5.3810 & 21.1604 & 378 \\
\hline Foreign patents $* \mathrm{R} \& \mathrm{D}$ expense deductibility & 4.6951 & 18.4840 & 378 \\
\hline Foreign patents $* \mathrm{R} \& \mathrm{D}$ incentives (foreign) & -0.6773 & 2.8683 & 378 \\
\hline
\end{tabular}

Note: The table presents means and standard deviations of variables used in the regressions.

Foreign Patents and Domestic Tax Incentives

\begin{tabular}{lcc}
\hline & \multicolumn{2}{c}{ Dependent Variable: } \\
& Change in Number of Foreign Patents \\
\hline Constant & -14.4802 & -11.9398 \\
& $(7.4138)$ & $(7.3321)$ \\
Change in domestic patents & 0.0590 & 0.0587 \\
& $(0.0144)$ & $(0.0143)$ \\
R\&D expense deductibility, 1991 & 13.5946 & 9.5607 \\
& $(7.1326)$ & $(7.1384)$ \\
Change in R\&D tax incentives & -30.7697 & -26.4124 \\
(foreign) & $(12.8296)$ & $(12.3228)$ \\
Percent foreign sales, 1991 & & 4.6708 \\
$R^{2}$ & .513 & $(2.4622)$ \\
$N$ & 378 & .516 \\
\end{tabular}

Note: The table reports estimated coefficients from OLS regressions. The dependent variable is the difference between the number of new foreign patents taken out during 1988-1991 (inclusive) and the number taken out during 1983-1986 (inclusive). "Change in domestic patents" is the difference between the number of new domestic patents taken out during 1988-1991 (inclusive) and the number taken out during 1983-1986 (inclusive). "R\&D expense deductibility, 1991" equals the fraction of domestic R\&D expenses that firms can deduct against their domestic tax liabilities in 1991. "Change in R\&D tax incentives (foreign)" equals the change in the required cost of capital for a \$1 investment in domestic R\&D intended to enhance foreign profitability. "Percent foreign sales, 1991" equals the fraction of a firm's sales that are foreign in 1991. Heteroskedasticity-consistent standard errors are in parentheses. 
The negative and significant estimated value of $\beta_{3}$ implies that greater deductibility of $R \& D$ expenses in 1991 is associated with increased foreign patenting. Specifically, lower tax costs of performing R\&D in the United States for use abroad are associated with greater foreign patents in the second (1988-1991) period relative to the first (1983-1986). In order to interpret the magnitude of the estimated value of $\beta_{3}$, it is important to bear in mind the construction of the R\&D tax incentive variable, and specifically, the use of average foreign tax rates in place of $\beta_{i t}$. Because a 10 percent difference in average foreign tax rates is generally sufficient to move firms between excess and deficit foreign tax credit status, it follows that the estimated value of $\beta_{3}$ (without this correction) overstates by a factor of ten the impact of changes in the tax treatment of royalties. The estimated coefficient of -30.8 in column (1) therefore implies that changing the domestic taxation of foreign source royalties from taxable to not taxable, would, for a firm with the mean value of $\alpha_{i t}=0.88$, be responsible for 1.1 additional foreign patents over the 1988-1991 period. Given the sample mean value of 5.4 foreign patents over the 1983-1986 period, this estimate implies that the cross elasticity of foreign patents with respect to the after-tax cost of domestic $\mathrm{R} \& \mathrm{D}$ directed at foreign markets is between 0.2 and 0.4 . This estimate is of the same order of magnitude, though of a different sign, as estimates of international R\&D and royalty substitutability reported by Hines (1995). These behavioral elasticities are considerably smaller than an own-price R\&D demand elasticity of unity or greater, as reported by Hall (1993) and Hines (1993).

Column (2) of table 8.5 presents estimated coefficients from a regression that adds as an independent variable the 1991 ratio of foreign to total sales. The purpose of this somewhat ad hoc addition is to control for a form of unobserved heterogeneity, in which firms that differ in their degrees of multinationality also differ in other unobserved dimensions that affect changes in foreign patenting. Firms with greater foreign sales in 1991 show faster growth of foreign patenting, although in other ways the results presented in column (2) differ little from those presented in column (1). The estimated tax effects in the column (2) regression are somewhat smaller than those in the first specification of the equation, but remain significant and of the same sign.

Table 8.6 reports results from a different specification of equation (12):

$$
\begin{aligned}
P_{i t}^{*}-P_{i t-1}^{*}= & \beta_{1}\left(P_{i t}-P_{i t-1}\right)+\beta_{2} P_{i t-1}^{*}+\beta_{2} P_{i t-1}^{*} \alpha_{i t}+\beta_{3} P_{i t-1}^{*} \lambda_{i t} \\
& +\beta_{4} X_{i t}+u_{i t}, \\
\lambda_{i t} \equiv & {\left[\frac{\left(1-\alpha_{i t} \tau_{t}\right)}{\left(1-\beta_{i t} \tau_{t}\right)}\right]-\left[\frac{\left(1-\alpha_{i t-1} \tau_{t-1}\right)}{\left(1-\beta_{i t-1} \tau_{t-1}\right)}\right] }
\end{aligned}
$$

The specification in equation (14) is a close variant of equation (13), the difference being that the independent variables are now interacted with 


\begin{tabular}{|c|c|c|c|c|}
\hline \multirow[b]{2}{*}{ Constant } & \multicolumn{4}{|c|}{$\begin{array}{l}\text { Dependent Variable: } \\
\text { Change in Number of Foreign Patents }\end{array}$} \\
\hline & $\begin{array}{c}0.4650 \\
(0.3300)\end{array}$ & & $\begin{array}{r}-0.3125 \\
(0.0094)\end{array}$ & \\
\hline Change in domestic patents & $\begin{array}{c}0.0441 \\
(0.0094)\end{array}$ & $\begin{array}{c}0.0443 \\
(0.0093)\end{array}$ & $\begin{array}{l}0.0441 \\
(0.0094)\end{array}$ & $\begin{array}{c}0.0441 \\
(0.0094)\end{array}$ \\
\hline First-period foreign patents & $\begin{array}{r}-7.0090 \\
(2.9126)\end{array}$ & $\begin{array}{r}-6.9122 \\
(2.8834)\end{array}$ & $\begin{array}{r}-6.9873 \\
(2.9001)\end{array}$ & $\begin{array}{r}-7.0120 \\
(2.9079)\end{array}$ \\
\hline $\begin{array}{l}\text { Foreign patents } * \text { R\&D expense } \\
\text { deductibility }\end{array}$ & $\begin{array}{c}6.1417 \\
(2.2333)\end{array}$ & $\begin{array}{c}6.0594 \\
(2.5081)\end{array}$ & $\begin{array}{c}6.1158 \\
(2.5218)\end{array}$ & $\begin{array}{r}6.1389 \\
(2.5281)\end{array}$ \\
\hline $\begin{array}{l}\text { Foreign patents } * \mathrm{R} \& \mathrm{D} \text { incentives } \\
\quad \text { (foreign) }\end{array}$ & $\begin{array}{rl}-1 & 14.6054 \\
(5.8364)\end{array}$ & $\begin{array}{r}-14.4423 \\
(5.7862)\end{array}$ & $\begin{array}{r}-14.5892 \\
(5.8173)\end{array}$ & $\begin{array}{r}-14.6249 \\
(5.8309)\end{array}$ \\
\hline Percent foreign sales, 1991 & & & $\begin{array}{c}2.4524 \\
(1.9554)\end{array}$ & $\begin{array}{r}1.7459 \\
(1.1536)\end{array}$ \\
\hline$R^{2}$ & .640 & .654 & .641 & .656 \\
\hline$N$ & 378 & 378 & 378 & 378 \\
\hline
\end{tabular}

Note: The table reports estimated coefficients from OLS regressions. The dependent variable is the difference between the number of new foreign patents taken out during 1988-1991 (inclusive) and the number taken out during 1983-1986 (inclusive). "Change in domestic patents" is the difference between the number of new domestic patents taken out during 1988-1991 (inclusive) and the number taken out during 1983-1986 (inclusive). "First-period foreign patents" is the number of foreign patents taken out between 1983 and 1986. "Foreign patents * R\&D expense deductibility" equals the product of foreign patents taken out between 1983 and 1986 and the fraction of domestic R\&D expenses that firms can deduct against their domestic tax liabilities in 1991. "Foreign patents * R\&D incentives (foreign)" equals the product of foreign patents taken out between 1983 and 1986 and the change in the required cost of capital for a $\$ 1$ investment in domestic R\&D intended to enhance foreign profitability. "Percent foreign sales, 1991" equals the fraction of a firm's sales that are foreign in 1991. Heteroskedasticityconsistent standard errors are in parentheses.

numbers of foreign patents over 1983-1986. The specification in equation (14) is intended to provide a natural scaling for the price-type variables that appear on the right side of equation (12).

The results reported in table 8.6 are quite consistent with those reported in table 8.5. Firms with rapidly growing domestic patenting exhibit faster than average growth of foreign patenting. Of particular interest is the estimated -14.6 value of $\beta_{3}$ in the regression reported in column (1). Again taking a 10 percent change in the average foreign tax rate to be sufficient to change foreign tax credit status, it follows that the -14.6 coefficient implies roughly a 0.5 cross-price elasticity of foreign $R \& D$ with respect to the cost of domestic R\&D directed at foreign markets. As is evident from the results reported in columns (2) through (4) of table 8.6, minor specification changes affect this estimated behavioral elasticity very little.

\subsection{Conclusion}

This study considers the effect of changes in the after-tax cost of R\&D on subsequent patenting by U.S. firms in the United States and abroad. 
The purpose is to estimate the impact of tax policy on the location of successful inventive activity. Tax policy affects patent location by influencing the location of R\&D and therefore the likelihood of producing patentable inventions. Recent U.S. tax changes affect some U.S. firms more strongly than others, making it possible to estimate the effect of tax policies on innovation by comparing reactions to the changes.

The results indicate that firms for which after-tax costs of performing R\&D in the United States for use abroad rose most rapidly after 1986 exhibited the slowest growth of foreign patenting in subsequent years. Estimated cross-price elasticities of foreign patenting with respect to the cost of domestic R\&D directed at foreign markets vary between 0.2 and 0.5 . This suggests not only that tax incentives influence subsequent patenting patterns, but that foreign and domestic innovative activities are complements at the firm level. Although this is an intuitively appealing finding, it is inconsistent with available evidence of the international substitutability of R\&D activity as measured at the aggregate level. This raises the interesting possibility that domestic and foreign innovation, although complements for individual firms, become substitutes between economies due to induced effects on the composition of industry or for other reasons.

\section{References}

Altshuler, Rosanne, and T. Scott Newlon. 1993. The effects of U.S. tax policy on the income repatriation patterns of U.S. multinational corporations. In Studies in international taxation, ed. Alberto Giovannini, R. Glenn Hubbard, and Joel Slemrod, 77-115. Chicago: University of Chicago Press.

Altshuler, Rosanne, T. Scott Newlon, and William C. Randolph. 1995. Do repatriation taxes matter? Evidence from the tax returns of U.S. multinationals. In The effects of taxation on multinational corporations, ed. Martin Feldstein, James R. Hines Jr., and R. Glenn Hubbard, 253-72. Chicago: University of Chicago Press.

Blomström, Magnus. 1991. Host country benefits of foreign investment. In Foreign investment, technology and economic growth, ed. Donald McFetridge, 93-108. Calgary: University of Calgary Press.

Blomström, Magnus, and Ari Kokko. 1995. Policies to encourage inflows of technology through foreign multinationals. World Development 23 (3): 1-10.

Bound, John, Clint Cummins, Zvi Griliches, Bronwyn Hall, and Adam Jaffe. 1984. Who does $\mathrm{R} \& \mathrm{D}$ and who patents? In $R \& D$, patents and productivity, ed. Zvi Griliches, 21-54. Chicago: University of Chicago Press.

Davidson, W. H., and Donald G. McFetridge. 1984. International technology transactions and the theory of the firm. Journal of Industrial Economics 32 (3): 253-64.

Dun \& Bradstreet Ltd. 1989. Who owns whom directory of corporate affliations, various vols. High Wycombe, U.K.: Dun and Bradstreet International.

Ethier, Wilfred J., and James R. Markusen. 1996. Multinational firms, technology diffusion and trade. Journal of International Economics 41 (1-2): 1-28. 
Griliches, Zvi. 1992. The search for R\&D spillovers. Scandinavian Journal of Economics 94 (Suppl.): 29-47.

Hall, Bronwyn H. 1993. R\&D tax policy during the 1980s: Success or failure? In Tax policy and the economy, vol. 7, ed. James M. Poterba, 1-35. Cambridge: MIT Press.

Hall, Bronwyn H., Adam B. Jaffe, and Manuel Trajtenberg. 2000. Market value and patent citations: A first look. NBER Working Paper no. 7741. Cambridge, Mass.: National Bureau of Economic Research, June.

Hartman, David G. 1985. Tax policy and foreign direct investment. Journal of Public Economics 26 (1): 107-21.

Hines, James R., Jr. 1991. The flight paths of migratory corporations. Journal of Accounting, Auditing, and Finance 6 (4): 447-79.

Hines, James R., Jr. 1993. On the sensitivity of R\&D to delicate tax changes: The behavior of U.S. multinationals in the 1980s. In Studies in international taxation, ed. Alberto Giovannini, R. Glenn Hubbard, and Joel Slemrod, 149-87. Chicago: University of Chicago Press.

Hines, James R., Jr. 1994. No place like home: Tax incentives and the location of R\&D by American multinationals. In Tax policy and the economy, vol. 8, ed. James M. Poterba, 65-104. Cambridge: MIT Press.

Hines, James R., Jr. 1995. Taxes, technology transfer, and the R\&D activities of multinational firms. In The effects of taxation on multinational corporations, ed. Martin Feldstein, James R. Hines Jr., and R. Glenn Hubbard, 225-48. Chicago: University of Chicago Press.

Hines, James R., Jr. 1997. International taxation and corporate R\&D: Evidence and implications. In Borderline case: International tax policy, corporate research and development, and investment, ed. James M. Poterba, 39-52. Washington, D.C.: National Academy Press.

Hines, James R., Jr., and R. Glenn Hubbard. 1990. Coming home to America: Dividend repatriations by U.S. multinationals. In Taxation in the global economy, ed. Assaf Razin and Joel Slemrod, 161-200. Chicago: University of Chicago Press.

Hines, James R., Jr., and Eric M. Rice. 1994. Fiscal paradise: Foreign tax havens and American business. Quarterly Journal of Economics 109 (1): 149-82.

Jaffe, Adam B., Manuel Trajtenberg, and Rebecca Henderson. 1993. Geographic localization of knowledge spillovers as evidenced by patent citations. Quarterly Journal of Economics 108 (3): 577-98.

Jaffe, Adam B., and Manuel Trajtenberg. 1999. International knowledge flows: Evidence from patent citations. Economics of Innovation and New Technology 8 (1): $105-36$.

Lipsey, Robert E., Magnus Blomström, and Irving B. Kravis. 1990. R\&D by multinational firms and host country exports. In Science and technology: Lessons for development policy, ed. Robert E. Evenson and Gustav Ranis, 271-300. Boulder, CO: Westview Press.

Mansfield, Edwin, and Anthony Romeo. 1980. Technology transfer to overseas subsidiaries by U.S.-based firms. Quarterly Journal of Economics 95 (4): 737-50.

Mansfield, Edwin, David Teece, and Anthony Romeo. 1979. Overseas research and development by U.S.-based firms. Economica 46 (182): 187-96.

Scholes, Myron S., and Mark A. Wolfson. 1992. Taxes and business strategy: A planning approach. Englewood Cliffs, N.J.: Prentice-Hall.

Standard and Poors Compustat Service. Available at http://garnet.acns.fsu.edu/ $\sim$ ppeters/fin6842/exer/compu.html.

Teece, David J. 1976. The multinational corporation and the resource cost of international technology transfer. Cambridge, Mass.: Ballinger. 
Turro, John. 1993. U.S. enacts controversial budget legislation. Tax Notes International 16 (7): 435-38.

U.S. Congress. Joint Committee on Taxation. 1993. Summary of the President's revenue proposals. 103d Cong., 1st sess. Washington, D.C.: GPO.

U.S. Department of Commerce. Bureau of Economic Analysis. 1985. U.S. direct investment abroad: 1982 benchmark survey data. Washington, D.C.: GPO.

U.S. Department of Commerce. Bureau of Economic Analysis. 1992. U.S. direct investment abroad: 1989 benchmark survey, final results. Washington, D.C.: GPO.

U.S. Department of Commerce. Bureau of Economic Analysis. 1996. U.S. direct investment abroad: 1994 benchmark survey, final results. Washington, D.C.: GPO.

U.S. Department of the Treasury. 1983. The impact of the section 861-8 regulation on U.S. research and development. Washington, D.C.: GPO.

U.S. Department of the Treasury. 1995. The relationship between U.S. research and development and foreign income. Washington, D.C.: U.S. Department of the Treasury.

Wang, Jian-Ye, and Magnus Blomström. 1992. Foreign investment and technology transfer: A simple model. European Economic Review 36:137-55.

Zejan, Mario C. 1990. R\&D activities in affiliates of Swedish multinational enterprises. Scandinavian Journal of Economics 92:487-500.

\section{Comment Austan Goolsbee}

In this paper, Hines and Jaffe take up the important issue of whether domestic and foreign $R \& D$ are substitutes or complements. To do so, they use an interesting but indirect test based on changes to the tax price of doing R\&D in the two locations. They show that R\&D tax policy in the 1980 s changed the relative incentive to engage in $R \& D$ domestically but in a way that varied across companies depending on each one's foreign tax status. Using an extensive data source on foreign patents, they use this cross-sectional variation to show that firms whose domestic tax prices rose the most had the slowest growth rates of foreign patenting, and thus that the two types of R\&D must be complements.

The topic itself is quite important in ongoing discussions about tax and $\mathrm{R} \& \mathrm{D}$ policy. $\mathrm{R} \& \mathrm{D}$ is subsidized or encouraged in most developed countries for the presumed spillovers. Often the country's policy makers perceive that their R\&D efforts are directly competing with the policies of the other nations, but if there are strong complementarities, this will not be the case.

First, let me discuss the precise experiment they analyze. The paper begins with a firm investing in a foreign location and trying to decide whether to do the R\&D in the United States and then sell the product in

Austan Goolsbee is associate professor of economics at the University of Chicago Graduate School of Business and a faculty research fellow of the American Bar Foundation and the National Bureau of Economic Research. 
the foreign country (and pay royalties back to the United States), or to do the $R \& D$ and sell the product in the foreign country. Obviously the relative tax treatment of $R \& D$ in the two countries will matter for the decision and we know that the tax treatment varied substantially (perhaps too much!) throughout the 1980s.

Normally, in a case like this, the researcher has only a time series on tax policy and it is difficult to identify the impact of taxes from other time series variables. Hines and Jaffe make the important observation that the changes to tax policy also generate cross-sectional variation in the relative R\&D price.

Oversimplifying somewhat, before the Tax Reform Act of 1986 (TRA 1986), companies could deduct all of their U.S. R\&D expenses from their U.S. income. After 1986, they could deduct only part of it from U.S. income because the rest was viewed to be intended for foreign markets. Other countries, however, do not give these companies any credit for this U.S. R\&D, so the impact of this change varies by foreign tax status. For firms with deficit credits (also known as excess limits), whose foreign tax rates are lower than the U.S. rate, this is not a problem. Firms with excess credits, however, whose foreign tax rates are higher than the U.S. rate, lose the deductions because they have already "maxed out," if you will. Hines and Jaffe argue, therefore, that changes to the allocation rules pre- and post-TRA 1986 should impact the R\&D of excess credit companies differently than they would deficit credit companies. Assuming that unobservable factors affect both of these types of companies equally, it is possible to identify the impact of taxes based on the change in the crosssectional R\&D price.

Because no data on the domestic and foreign R\&D by firm are readily available to examine this issue, Hines and Jaffe turn to the extremely detailed NBER/Case Western Reserve University (CWRU) database on foreign patents of U.S. companies described in Jaffe and Trajtenberg (1999). This data is an exciting resource for economists and it is good to see it filtering into public economics and tax work. Essentially they can get a measure of the foreign tax rate from Standard and Poors Compustat Service and, classifying patents as a proxy for foreign R\&D, look at the natural experiment just described.

The results show that there must be very substantial complementarity between domestic and foreign R\&D. As this is an indirect test based on a natural experiment methodology, it is important to consider the plausibility of the magnitudes and the validity of the experiment before being fully convinced by this type of evidence.

The first quibble I have with the paper is that I do not think that the coefficients are estimated as precisely as the tables portray. There are two time periods in the study (a before and after), and 378 firms; but the 378 firms are unlikely to be completely independent of one another. In the 
extreme, one might argue that the identification comes strictly from comparing two types of firms-deficit and excess credit. Accounting for the dependence of the residuals across firms within tax status classes would make the standard errors larger, possibly a great deal larger.

My second reservation about the results relates to their magnitude. The paper notes that the results in table 8.4 suggest that for the average firm, moving from taxable to nontaxable would result in eleven additional foreign patents from 1988 to 1991. Note, however, that the mean number of foreign patents is only 5.4- so this is more than a 100 percent increase. The means in table 8.2 do not make it easy to calculate an elasticity, but my back-of-the-envelope computation suggests an elasticity of around -2 . Remember, this is not a standard own-price elasticity. It is more like a cross-price elasticity, and as such is very large, indeed. Hines (1993) found that the own-price elasticity of domestic R\&D in this same context was between -1.2 and -1.8 . This very strong complementarity result is even more puzzling when we consider the findings of Hines (1995), using aggregate data, that foreign and domestic $\mathrm{R} \& \mathrm{D}$ are substitutes.

Further, the magnitude is probably biased toward zero by the role of measurement error and policy uncertainty. As Hines and Jaffe painstakingly recount the myriad changes to the international $R \& D$ incentives over the time period, one cannot help but notice how frequently the major changes take place. In the empirical work, they divide the sample into two parts: 1983-1986 and 1988-1991. This type of grouping is probably the right thing to do given the numerous changes, but it should introduce significant measurement error. It is hard to imagine any firm taking existing, statutory tax policy as being permanent, and this expectations problems is likely to bias the results downward.

Regardless, given the natural experiment methodology, it is not unusual to ask whether this is a valid experiment and whether there is a valid control group. The basis of the paper is a comparison of the patent responses of excess and deficit credit firms in the two periods. One may not be a valid control group for the other, however, even when eliminating aggregate factors. It would take some more convincing to establish the validity.

By definition, the two groups must be investing in different countries, for example. It would be helpful to know whether low-tax countries (which are, on average, the investment locations of deficit credit firms) are concentrated in certain geographic regions, and so on. Over the 1980s, there were some major economic shifts that were not neutral across regions, that might influence patenting probabilities, and that are probably correlated with the tax changes. Things like the tremendous fall of oil prices or the dramatic shifts in exchange rates around the same time as TRA 1986 are likely to have impacted companies differently if they had invested in Asia versus Europe versus the Middle East, for example; and, as omitted variables correlated with the tax change, could generate the tax results. In the 
years after TRA 1986, there were also some substantial tax changes in other countries that may have similarly influenced incentives. Each of these issues deserves more discussion to assure us that the estimated impact is not spurious.

To summarize, in this paper, Hines and Jaffe present a creative approach to establishing the complementarity of foreign and domestic R\&D and the results are striking but not conclusive. It is, perhaps, unrealistic to expect that we would find the results completely definitive because they are based on indirect evidence and one can always quibble with the data or the experiment in such studies. I hope that their effort, however, will encourage others to use tax policy as the source of experiments that can illuminate important areas of research on $\mathrm{R} \& \mathrm{D}$.

\section{References}

Hines, James R., Jr. 1993. On the sensitivity of R\&D to delicate tax changes: The behavior of U.S. multinationals in the 1980s. In Studies in international taxation, ed. Alberto Giovannini, R. Glenn Hubbard, and Joel Slemrod, 149-87. Chicago: University of Chicago Press.

Hines, James R., Jr. 1995. Taxes, technology transfer, and the R\&D activities of multinational firms. In The effects of taxation on multinational corporations, ed. Martin Feldstein, James R. Hines Jr., and R. Glenn Hubbard, 225-48. Chicago: University of Chicago Press.

Jaffe, Adam B., and Manuel Trajtenberg. 1999. International knowledge flows: Evidence from patent citations. Economics of Innovation and New Technology 8 (1): 105-36.

Standard and Poors Compustat Service. Available at http://garnet.acns.fsu.edu/ $\sim$ ppeters/fin6842/exer/compu.html. 
